\title{
Delineating the antigenotoxic and anticytotoxic potentials of 4-methylimidazole against ethyl methanesulfonate toxicity in bone marrow cell of swiss albino mice
}

\author{
Norizadeh Tazehkand $\mathrm{M}^{1}$, Topaktas $\mathrm{M}^{2}$, Yilmaz $\mathrm{MB}^{5}$, Hajipour $\mathrm{O}^{3}$, Valipour $\mathrm{E}^{4}$ \\ Department of Biotechnology, Institute of Basic and Applied Sciences, Cukurova University, Adana, Turkey. \\ mostafa_noorizadeh@yahoo.com
}

\begin{abstract}
4-Methylimidazole (4-MEI) is mostly used in beverages and coloring food, dark beers and common brands of cola drinks, which may contain more than $100 \mu \mathrm{g}$ of this compound per 12-ounce serving. This study was aimed to investigate the antigenotoxic and anticytotoxic effects of 4-MEI (100, 130 and $160 \mathrm{mg} / \mathrm{kg})$ against ethyl methanesulfonate $(240 \mathrm{mg} / \mathrm{kg})$ using chromosome aberrations (CAs) and Mitotic index (MI) tests in bone marrow cells of Swiss Albino Mice at $12 \mathrm{~h}$ and $24 \mathrm{~h}$ treatment periods. So, the $t$-test was used for the statistical analysis. In this research, 4-MEl at all concentrations for $12 \mathrm{~h}$ treatment period reduced chromosomal aberrations and at 130 and $160 \mathrm{mg} / \mathrm{kg}$ concentrations for $24 \mathrm{~h}$ treatment period increased chromosomal aberrations induced by EMS $(240 \mathrm{mg} / \mathrm{kg})$, but th ese reductions and increases were not significant. Also, intraperitoneal injection of 4-MEI at doses of 100,130 and $160 \mathrm{mg} / \mathrm{kg}$ combined with EMS $(240 \mathrm{mg} / \mathrm{kg})$ showed that the mitotic index was decreased at 100 and $130 \mathrm{mg} / \mathrm{kg}$ for $12 \mathrm{~h}$ and $130 \mathrm{mg} / \mathrm{kg}$ for $24 \mathrm{~h}$ treatment periods, when compared to positive sample (EMS), but did not show any statistically difference from the EMS treated group. It can be concluded that 4-MEI might not be antigenotoxic and protective effects in bone marrow cells of Swiss Albino Mice, because 4-MEI could not reduce the chromosomal aberrations induced by EMS (Tab. 2, Fig. 2, Ref. 36). Text in PDF www.elis.sk. KEY WORDS: 4-Methylimidazole, ethyl methansulfonate, antigenotoxicity, anticytotoxicity, chromosome aberration.
\end{abstract}

\section{Introduction}

Food coloring is used both in commercial food production and in household cooking (1). More than 2,500 items of food coloring additives are used for various purposes, including coloring and increase nutrient value (2). One of food color is 4-Methylimidazole (4-MEI), which has a yellow color. 4-MEI was utilized by IARC (International Agency for Research on Cancer) in 2011 and set into group 2B20 (3). 4-MEI is used as a chemical intermediate, crude material or component in the manufacture of pharmaceuticals, photographic and photothermographic chemicals, dyes and pigments and agricultural chemicals (4). 4-MEI is unintentionally found in our foods. Caramel color (which is the most used beverage coloring and food), dark beers and common brands of cola drinks

${ }^{1}$ Department of Biotechnology, Institute of Basic and Applied Sciences, Cukurova University, Adana, Turkey, ${ }^{2}$ Faculty of Science and Letters, Department of Biology, Cukurova University, Adana, Turkey, ${ }^{3}$ Department of Molecular Biology, Institute of Basic and Applied Sciences, Pamukkale University, Denizli, Turkey, ${ }^{4}$ Department of Biotechnology, Institute of Basic and Applied Sciences, Cukurova University, Adana, Turkey, and ${ }^{5}$ Faculty of Medicine, Department of Medical Biology, Cukurova University, Adana, Turkey

Address for correspondence: M. Norizadeh Tazehkand, Department of Biotechnology, Institute of Basic and Applied Sciences, Cukurova University, Adana 01330, Turkey.

Phone: +90.5372891027

Acknowledgements: This investigation was supported by a grant from Cukurova University science research project (FDK-2014-2617). may comprise more than $100 \mu \mathrm{g}$ of this compound per 12-ounce serving (5). Ishie et al reported that LD50 values of 4-MEI are 370 $\mathrm{mg} / \mathrm{kg}$ orally and $165 \mathrm{mg} / \mathrm{kg}$ intraperitoneally for mice; $120 \mathrm{mg} /$ $\mathrm{kg}$ intraperitoneally for rabbits; and $590 \mathrm{mg} / \mathrm{kg}$ orally and $210 \mathrm{mg} /$ $\mathrm{kg}$ intraperitoneally for chickens (6). NTP (The National Toxicology Program) reported a two-year consuming cancer assessment of 4-MEI in mice and rats. The results of this research showed a clear evidence of carcinogenic activity of 4-MEI in male and female B6C3F1 mice based on increased incidences of alveolar/ bronchiolar neoplasms. In accordance with this result, the NTP found an equivocal evidence of carcinogenic activity in female rats $(\mathrm{F} 344 / \mathrm{N})$ based on increased incidences of mononuclear cell leukemia and no evidence of carcinogenic activity in male rats. However, the manufacture of certain artificial caramel colorings can lead to the formation of carcinogens $(4,7)$. In contrast, other experimental studies reported that 4-MEI provide chemopreventive effects against some cancer $(7,8)$. Decreased incidences of tumors in rats were mentioned in the NTP results, but they were not given much prominence, because the NTP commonly focuses on cytotoxic identification rather than cancer prevention $(4,7)$.

CAs (chromosome aberrations) is a widespread method for study of many drugs and other material on genetic material or chromosome (9). Antigenotoxic effect of some food coloring were reported from other researchers. For example, chemopreventive activity of chlorophyllin was showed by Drosophila system $(10,11,12)$. Similar results were observed by Izawa et al (1997), who observed red and yellow pigments from Monascus, which has an inhibitory effect 
against the bacterial mutagenicity of heterocyclic amines (13). In the view of the extensively use of 4-MEI by humans, it would be of interest if further studies were carried out for obtaining more information on the possible in vivo antigenotoxic effects of 4-MEI against other genotoxic materials. Consequently, this study was aimed to investigate the antigenotoxic effects of 4-MEI against ethyl methanesulfonate (EMS) using chromosome aberrations (CAs) and Mitotic index (MI) tests in bone marrow cells of Swiss Albino Mice.

\section{Materials and methods}

\section{Chemicals}

In this research, the test substance (4-MEI) was purchased from Sigma and its properties are shown in Figure 1.

Lot No: 08302BF

Chemical Formula: $\mathrm{C}_{4} \mathrm{H}_{6} \mathrm{~N}_{2}$

Molecular Weight: 82.11

Synonym: 1H-Imidazole, 4-methyl (9Cl); imidazole, 4-methyl; 4(5)-methylglyoxaline; 4(5),4(5)-methylimidazole; 5-methylimidazole

Trade name: 4-MEI

PubChem : 13195

Molecular weight: $82.10 \mathrm{~g} \mathrm{~mol}^{-1}$

Appearance: Slightly yellowish solid

Density : $1.02 \mathrm{~g} / \mathrm{cm} 3$

Melting point : 46 to $48^{\circ} \mathrm{C}\left(115\right.$ to $118^{\circ} \mathrm{F} ; 319$ to $\left.321 \mathrm{~K}\right)$

Boiling point : $263^{\circ} \mathrm{C}\left(505^{\circ} \mathrm{F} ; 536 \mathrm{~K}\right)$

CAS Number: 822-36-6

Purity: $98 \%$

In this study, colchicine (CAS No. C-9754), $\mathrm{NaCl}$ (CAS No. 7647-14-5), $\mathrm{KCl}$ (CAS No. 7447-40-7) ethyl methanesulfonate (EMS) (CAS No. 62-50-0) were purchased from Sigma and Giemsa (CAS No. 1092040100) was purchased from Merck and all test solutions were freshly prepared prior to experiment.

\section{Experimental animals}

Male and female Swiss Albino Mice, 6-8 weeks old and weighing about 33-40 g, were obtained from the Experimental Research and Application Centre of Cukurova University, Turkey. They were kept in polypropylene shoebox cages with a grill top and were acclimatized to the control diet for 1 week. Animals were fed with the standard diet and water. Three animals were housed per cage and were maintained in a controlled environmental condition of temperature and $\left(22 \pm 2{ }^{\circ} \mathrm{C}\right)$ humidity $(45-60 \%)$ on alternatively $12 \mathrm{~h}$ dark/light cycles. The study was approbated by the Cukurova university Institutional animal Ethics Committee (FDK-2014-

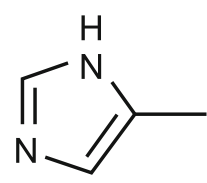

Fig. 1. The chemical structure of 4-methylimidazole.
2617) and all experiments were accomplished in accordance with the advisors of the ethics committee.

\section{EMS administration}

Ethyl methanesulfonate (EMS) well-known mutagenic and clastogenic agents in in vivo test system were used as a genotoxic agent (14). Sub-lethal high doses of EMS (240 mg/kg b.w) was employed (12 or 24 hours before sacrificed of the animals), as earlier established by Riaz and Vasudev (15). The required volumes of EMS $(0.5 \mathrm{~mL})$ were dissolved in double distilled water administered intraperitoneally (i.p.).

\section{Experimental protocol}

After the acclimatization period (one week), animals were treated through intraperitonial injections with 100, 130 and 160 $\mathrm{mg} / \mathrm{kg}$ body weight were administered. 4-MEI administered as single dose mixed with $240 \mathrm{mg} / \mathrm{kg}$ EMS in $0.5 \mathrm{~mL}$ per mouse intraperitoneal to 6 animals (three male and three female). The experimental animals were divided into nine groups, each group comprising of six animals (three male and three female)

1. Control group (untreated control): The control groups only received normal diet (pellet and water).

2. Positive control group (12 hours treatment): The positive control groups received a single intraperitoneal injection of $240 \mathrm{mg} / \mathrm{kg}$ Ethyl methanesulfonate dissolved in double distilled water 12 hours before test (12 hours before sacrificed).

3. Group 3: Received a mixture of $100 \mathrm{mg} / \mathrm{kg} 4-\mathrm{MEI}$ and $240 \mathrm{mg} /$ $\mathrm{kg}$ EMS dissolved in double distilled water 12 hours before test (12 hours before sacrificed).

4. Group 4: Received a mixture of $130 \mathrm{mg} / \mathrm{kg} 4-\mathrm{MEI}$ and $240 \mathrm{mg} /$ $\mathrm{kg}$ EMS dissolved in double distilled water 12 hours before test (12 hours before sacrificed).

5. Group 5: Received a mixture of $160 \mathrm{mg} / \mathrm{kg} 4-\mathrm{MEI}$ and $240 \mathrm{mg} /$ $\mathrm{kg}$ EMS dissolved in double distilled water 12 hours before test (12 hours before sacrificed).

6. Positive control group ( 24 hours treatment): The positive control groups received a single intraperitoneal injection of $240 \mathrm{mg} / \mathrm{kg}$ Ethyl methanesulfonate dissolved in double distilled water 24 hours before test ( 24 hours before sacrificed).

7. Group 7: The a mixture of $100 \mathrm{mg} / \mathrm{kg} 4-\mathrm{MEI}$ and $240 \mathrm{mg} / \mathrm{kg}$ EMS dissolved in double distilled water 24 hours before test (24 hours before sacrificed).

8. Group 8: Received a mixture of $130 \mathrm{mg} / \mathrm{kg} 4-\mathrm{MEI}$ and $240 \mathrm{mg} /$ $\mathrm{kg}$ EMS dissolved in double distilled water 24 hours before test ( 24 hours before sacrificed).

9. Group 9: Received a mixture of $160 \mathrm{mg} / \mathrm{kg} 4-\mathrm{MEI}$ and $240 \mathrm{mg} /$ $\mathrm{kg}$ EMS dissolved in double distilled water 24 hours before test (24 hours before sacrificed).

In this research, colchicine $(3 \mathrm{mg} / \mathrm{kg}$ body weight: $0.5 \mathrm{~mL})$, a spindle fiber inhibitor that arrests cells at metaphase was also administered by intraperitoneal 2 hours before the animals were sacrificed (16). So, animals were sacrificed by cervical dislocations at 12 hours and 24 hours (four groups 12 hours and four groups 24 hours) after the treatments and bone marrow cells were harvested. 


\section{0-294}

\section{Preparation of bone marrow metaphase chromosome}

These animals were sacrificed by cervical dislocation and bone marrow chromosomal aberrations assay was employed to determine any clastogenic effects in dividing cells, which were in the metaphase. The bone marrow was processed and slides were prepared by routine standard air dry technique (17). In this method, the femur bones were dissected from the animals and the bone marrow was aspirated using physiologic serum $(5 \mathrm{ml})$. The suspension was then centrifuged for 5 minutes at $2000 \mathrm{rpm}$ then, the supernatant was decanted. After that, the cells treated with 0.4 $\% \mathrm{KCl}\left(37^{\circ} \mathrm{C}\right.$, for 35 minute $)$ as the hypotonic solution and the suspension was centrifuged for 10 minutes at $1200 \mathrm{rpm}$ and supernatant was decanted. The cells fixed in cold methanol: glacial acetic acid $(3: 1)$ for $20 \mathrm{~min}$ at room temperature. The treatment with fixative was repeated three times. Then the cells were spread on cold glass slides $\left(4^{\circ} \mathrm{C}\right)$ and air-dried. The slides were stained with Giemsa ( $5 \%$ in Sorensen buffer) for $8 \mathrm{~min}$ (18).

\section{Chromosomal aberration analysis}

One hundred metaphases of the bone marrow cells were analyzed for the presence of CA (chromosomal aberrations). The CA was classified according to the ISCN (International System for Human Cytogenetic Nomenclature) (19). The number of the CA was obtained by calculating the percentage of metaphases at each concentration and treatment period that showed structural chromosome aberrations. Structural CAs scoring was done in the following categories: chromatid-type aberrations (exchanges, breaks and sister union) and chromosome-type aberrations (rings, breaks and dicentrics). Chromosome aberrations were evaluated in 100-well-spread metaphases per animal (in total, 600 metaphases per concentration or treatment periods) (20). Gaps were not evaluated as CA, according to Mace et al (21).

\section{Mitotic index analysis}

Mitotic index (MI) was analyzed in order to understand the effect of 4-MEI, EMS mixture on cell proliferation in different treatment and different times. Mitotic index was determined by analyzing 3000 cells from each animal and scoring the cells that were in metaphase. The Mitotic index was calculated by using the formula below (22).
Mitotic Index $=100 \mathrm{x}$ cells in metaphase $/ 3000$

\section{Statistical analysis}

Student $t$-test was utilized for establishing the statistical significance of chromosome aberration and mitotic index data obtained from microscopic analyses were compared to the corresponding control and the positive control groups. Concentration-response relationships were determined from the correlation and regression coefficients for the percentage of cells with CA, as well as for the mean MI $(23,24)$.

\section{Results}

The results of chromosome aberrations analysis in male and female Swiss Albino Mice bone marrow cells at metaphase stage when intraperitoneally injection only EMS as a dose $(240 \mathrm{mg} / \mathrm{kg}$ body weight) and 4-MEI at various doses (100, 130 and $160 \mathrm{mg} /$ $\mathrm{kg}$ body weight) combined with EMS (240 $\mathrm{mg} / \mathrm{kg}$ body weight) are summarized in Table 1.

The result of this study showed that the EMS significantly induced the CAs at 12 and $24 \mathrm{~h}$ treatment periods in positive control sample. In the combination groups (4-MEI + EMS) except $160 \mathrm{mg} / \mathrm{kg}$ for $12 \mathrm{~h}$ and $100 \mathrm{mg} /$ for $24 \mathrm{~h}$ percentage of CAs was significantly increased when compared to the control. 4-MEI + EMS as a mixture induced structural CAs as the positive control at $160 \mathrm{mg} / \mathrm{kg}$ in the $24 \mathrm{~h}$ treatment period. In addition, this increment in the CAs was found to be concentration-dependent for $24 \mathrm{~h}$ treatment period ( $p<0.252$ ) (Fig. 2). 4-MEI decreased the genotoxicity of EMS at all concentrations for $12 \mathrm{~h}$ treatment period in the bone marrow cells of Swiss Albino Mice, but this decrease was not significant when compared to the positive control (EMS). This means that 4-MEI might not have inhibition of chromosomal damage induced by EMS.

The effects of EMS as a dose (240 mg/kg body weight) and 4-MEI at various doses (100, 130 and $160 \mathrm{mg} / \mathrm{kg}$ body weight) combined with EMS $240 \mathrm{mg} / \mathrm{kg}$ body weight by intraperitoneally injection on the mitotic index are shown in Table 2. The mitotic index (MI) of EMS and EMS plus 4-MEI treated groups was decreased and showed statistically significant differences from the untreated control. In the combination groups, the MI was decreased at 100 and $130 \mathrm{mg} / \mathrm{kg}$ for $12 \mathrm{~h}$ and $130 \mathrm{mg} / \mathrm{kg}$ for $24 \mathrm{~h}$ treatment

Tab. 1. CA in bone marrow cells of Swiss Albino Mice treated with 4-MEI + EMS.

\begin{tabular}{|c|c|c|c|c|c|}
\hline \multicolumn{2}{|l|}{ Treatment } & \multirow{2}{*}{$\frac{\text { Structural CA }}{\text { 4-MEI+EMS Conc. }(\mathrm{mg} / \mathrm{kg})}$} & \multicolumn{3}{|c|}{ Percentage of cells } \\
\hline Test substance & Time (hr) & & Chromatid type & Chromosome type & with aberrations $\pm \mathrm{SE}$ \\
\hline Control & - & - & 0 & 6 & $1.00 \pm 0.258$ \\
\hline EMS & 12 & 240 & 20 & 3 & $3.83 \pm 0.401 \mathrm{a}_{3}$ \\
\hline 4-MEI+EMS & 12 & $100+240$ & 12 & 5 & $2.83 \pm 0.307 \mathrm{a}_{2}$ \\
\hline 4-MEI+EMS & 12 & $130+240$ & 15 & 7 & $3.66 \pm 0.422 \mathrm{a}_{3}$ \\
\hline 4-MEI+EMS & 12 & $160+240$ & 16 & 0 & $2.67 \pm 0.558$ \\
\hline$\overline{\mathrm{EMS}}$ & 24 & $240+240$ & 16 & 2 & $3.00 \pm 0.447 \mathrm{a}_{2}$ \\
\hline 4-MEI+EMS & 24 & $100+240$ & 15 & 3 & $3.00 \pm 0.577$ \\
\hline 4-MEI+EMS & 24 & $130+240$ & 19 & 0 & $3.16 \pm 0.543 \mathrm{a}_{2}$ \\
\hline 4-MEI+EMS & 24 & $160+240$ & 22 & 3 & $4.16 \pm 0.792 \mathrm{a}_{3}$ \\
\hline
\end{tabular}

Data are expressed as the mean values $( \pm$ SE) obtained from six mice bone marrow cells; $n=6$, a: significant from negative control; b: significant from positive control (EMS), $\mathrm{a}_{1} \mathrm{~b}_{1}: \mathrm{p}<0.05 ; \mathrm{a}_{2} \mathrm{~b}_{2}: \mathrm{p}<0.01 ; \mathrm{a}_{3} \mathrm{~b}_{3}: \mathrm{p}<0.001$ 


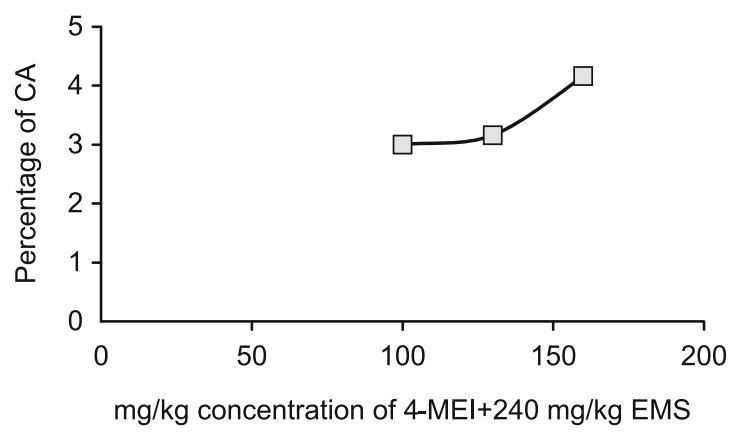

Fig. 2. The percentage of abnormal cells in Swiss Albino Mice treated with 4-MEI+EMS for $24 \mathrm{~h}$ treatment period $(\mathrm{p}<0.180)$.

periods when compared to the positive control groups $(240 \mathrm{mg} / \mathrm{kg}$ EMS), but did not show any statistically significant difference from the EMS treated group. In addition, no concentration-dependent effect was observed in the obtained results.

\section{Discussion}

The relationships between food, nutrition and cancer, and the knowledge that cancer might be a preventable disease has resulted in an increased interest in studying the mutagenic or antimutagenic potential of some dietary constituents (25). Considerable emphasis has been laid down on the use of dietary constituents to prevent the mutagen induced mutation or chromosomal damage due to their relative nontoxic effects. Ethyl methanesulfonate is well-known mutagenic and clastogenic agent in in vivo mouse test system. EMS was often used as a positive control in genotoxic test, both in in vitro and in vivo test system. The types of chromosomal aberrations induced by EMS as a positive control were reported to be chromosome break, chromatid break (14). According to our knowledge, this is the first study that addresses the antigenotoxic effects of 4-MEI in bone marrow cells of Swiss Albino Mice. In the present study, the results showed that intraperitoneally injection of 4-MEI at doses of 100,130 and $160 \mathrm{mg} / \mathrm{kg}$ combined with EMS $(240 \mathrm{mg} / \mathrm{kg})$ for $12 \mathrm{~h}$ treatment period was found to reduce chromosomal aberra-

Tab. 2. MI in bone marrow cells of Swiss Albino Mice treated with 4-MEI+ EMS for 12 and $24 \mathrm{~h}$.

\begin{tabular}{lccc}
\hline \multicolumn{3}{c}{ Treatment $\mathrm{f}$} \\
\hline Test substance & $\begin{array}{c}\text { Time } \\
(\mathrm{hr})\end{array}$ & $\begin{array}{c}\text { 4-MEI+EMS Conc. } \\
(\mathrm{mg} / \mathrm{kg})\end{array}$ & MI \pm SE \\
\hline Untreated Control & - & - & $5.532 \pm 0.315$ \\
EMS & 12 & 240 & $2.217 \pm 0.294 \mathrm{a}_{3}$ \\
4-MEI+EMS & 12 & $100+240$ & $1.943 \pm 0.230 \mathrm{a}_{3}$ \\
4-MEI+EMS & 12 & $130+240$ & $1.915 \pm 0.263 \mathrm{a}_{3}$ \\
4-MEI+EMS & 12 & $160+240$ & $2.320 \pm 0.182 \mathrm{a}_{3}$ \\
EMS & 24 & $240+240$ & $2.683 \pm 0.273 \mathrm{a}_{3}$ \\
4-MEI+EMS & 24 & $100+240$ & $2.308 \pm 0.334 \mathrm{a}_{3}$ \\
4-MEI+EMS & 24 & $130+240$ & $2.912 \pm 0.439 \mathrm{a}_{2}$ \\
4-MEI+EMS & 24 & $160+240$ & $2.250 \pm 0.279 \mathrm{a}_{3}$ \\
\hline
\end{tabular}

Data are expressed as the mean values $( \pm \mathrm{SE})$ obtained from six mice bone marrow cells; $\mathrm{n}=6$, a: significant from negative control; $\mathrm{b}$ : significant from positive control (EMS), $\mathrm{a}_{1} \mathrm{~b}_{1}: \mathrm{p}<0.05 ; \mathrm{a}_{2} \mathrm{~b}_{2}: \mathrm{p}<0.01 ; \mathrm{a}_{3} \mathrm{~b}_{3}: \mathrm{p}<0.001$. tions induced by the EMS, but these reductions were not significant. According to the findings of this research, it can be said that 4-MEI did not have antigenotoxic effect in bone marrow cells of Swiss Albino Mice. Many color additives including anthocyanin, annatto and bixin appear to be potent antimutagens and antigenotoxics against genotoxic reagents $(26,27,28)$. In contrast to $4-\mathrm{MEI}$, some of the food coloring have antigenotoxic effect against other genetoxic reagent. For example, Izawa et al (1997) observed that that red and yellow pigments from Monascus have an inhibitory effect against the bacterial mutagenicity of heterocyclic amines. Similarly, Edenharder and Tang (1997), reported the antimutagenic effect of purpurin, alizarin and other 10 anthraquinone compounds using the Ames test (29). In another study, chemopreventive activity of chlorophyll was shown by Drosophila system $(10,11,12)$. The number of reviews concerning the carcinogenicity and mutagenicity 4-MEI has been published. For example, The National Toxicology Program (NTP) in the study of the rodent cancer bioassay for 4-MEI in male and female animals (B6C3F1 mice). The results of this research showed that the carcinogenic activity of 4-MEI in male and female mice and led to the development of the lung tumors (8). Similar results were obtained by Hannah et al (2010) since both Coke and Pepsi soft drinks, which contain the same substance (4-MEI) induced the chromosomal abnormalities in the roots of Allium cepa treated for 2, 24, and 48 hours treatment times(30). Another study, Jensen et al (1983) reported that caramel was the important color additive in Cola soft drinks and it showed a mutagenic activity in Salmonella typhimurium TA 100(31). On the other hand, results obtained by Rayes (2008), showed that the Cola soft drink had toxic effects on the mice testicular cells (32). Overall, these available studies provided little evidence for the genotoxicity of 4-MEI.

The mitotic index is simply a measurement to determine the percentage of cells undergoing mitosis. Mitosis is the division of somatic cells when genetic information from one single cell is equally dispersed into two daughter cells. The mitotic index may be elevated during necessary processes to life, such as the normal growth of plants or animals, as well as cellular repair the sire of an injury (33). Cytotoxic effect is measured by mitotic index and other tests. In our research, we also used this parameter. Intraperitoneally injection of 4-MEI at doses of 100, 130 and $160 \mathrm{mg} / \mathrm{kg}$ combined with EMS (240 mg/kg) showed that the MI was decreased except $160 \mathrm{mg} / \mathrm{kg}$ 4-MEI + EMS $(240 \mathrm{mg} / \mathrm{kg})$ for $12 \mathrm{~h}$ and 100 and 160 $\mathrm{mg} / \mathrm{kg} 4-\mathrm{MEI}+\mathrm{EMS}(240 \mathrm{mg} / \mathrm{kg})$ for $24 \mathrm{~h}$ treatment periods when compared to the positive control ( $240 \mathrm{mg} / \mathrm{kg}$ EMS), but did not show any statistically significant differences from the EMS treated group. The neurotoxic syndrome of 4-MEI observed by Hidaka (1976) occurred soon after a high gavage dose of 4-MEI under conditions, where both metabolism and renal clearance were saturated (34). Imidazole's, especially those substituted at the 4-position, have been recognized as inhibitors of cytochromes P450. Hargreaves et al (1994) reported that 4-MEI was a strong inhibitor of p-nitrophenol hydrolase in rat liver. $\mathrm{p}$-Nitrophenol is a cytochrome $\mathrm{P} 450$ 2E1 substrate (35). 4-MEI forms complexes with heme-containing enzymes such as cytochrome P450 and results in an inhibition of mixed function oxidase activity (36). Supporting the present study, probable cytotoxic effect of 4-MEI has also a similar mechanism. 


\section{Conclusion}

In this research, no significant difference in CA and MI values was observed among the animals that received the EMS alone or in combination with 4-MEI (at various doses). It can be concluded that 4-MEI might not have antigenotoxic and protective effects in bone marrow cells of Swiss Albino Mice. However, it must be investigated in other test systems.

\section{References}

1. FDA.,CFR Title 21 Part 70: Color Additive Regulations, retrieved Feb., $2012,15$.

2. Toledo MF. Regulamentacao de Uso de Corantes Naturais. Arch Latinoam Nutr 1999; 49: 67-70.

3. IARC. Monographs on the evaluation of carcinogenic risks to humans $2011 ; 101$.

4. National Toxicology Program (NTP). NTPTechnical Report on the Toxicology and Carcinogenesis Studies of 4-Methylimidazole (CAS No. 822-36-6) in F344/N Rats and B6C3F1 Mic NTP TR-535. Research Triangle Park, NC 2007.

5. Jacobson MF. Petition to Bar the Use of Caramel Colorings Produced With Ammonia and Containing the Carcinogens 2-Methylimidazole and 4-Methylimidazole. Center Sci Publ Interest 2011; 1-11.

6. Nishie K, Waiss AC, Keyl AC. Toxicity of methylimidazoles. Toxicol Appl Pharmacol 1969; 14: 303-307.

7. Chan PC, Hill GD, Kissling GE, Nyska A. Toxicity and carcinogenicity studies of 4-methylimidazole in F344/N rats and B6C3F1 mice. Arch Toxicol 2008; 82: 45-53.

8. Murray FJ. Does 4-methylimidazole have tumor preventive activity in the rat? Food Chem Toxicol 2011; 49: 320-322.

9. Carrano AV, Natarajan AT. Consideration for population monitoring using cytogenetic techniques. Mutat Res 1988; 204: 379-406.

10. Negishi T, Rai H, Hayatsu H. Antigenotoxic activity of natural chlorophylls. Mutat Res 1997; 376: 97-100.

11. Negishi T, Nakano H, Kitamura A, Itome C, Shiotani T, Hayatsu H. Inhibitory activity of chlorophyllin on the genotoxicity of carcinogens in Drosophila. Cancer Lett 1994; 83: 157-164.

12. Olvera O, Zimmering S, Arceo C, Cruces M. The protective effect of chlorophyllin in treatment with chromium(VI) oxide in somatic cells of Drosophila. Mutat Res 1993; 301: 201-204.

13. Izawa S, Harada N, Watanabe T, Kotokawa N, Yamamoto A, Hayatsu H, Arimoto-Kobayashi S. Inhibitory effects of food-coloring agents derived from Monascus on the mutagenicity of heterocyclic amines. J Agric Food Chem 1997; 45: 3980-3984.

14. Guruprasad KP, Subramanian A, Singh VJ, Sharma RSK, Gopinath PM, Sewram S, Varier PM, Satyamoorthy K. Brahmarasayana protects against Ethyl methanesulfonate or Methyl ethanesulfonate induced chromosomal aberrations in mouse bone marrow cells. BMC Complement Altern Med 2012; 1: 112-113.

15. Riaz M, Vasudev V, Harish SK, Guruprasad KP. Inducible protective processes in animal systems: VI. Adaptive response to a low dose of Methyl methanesulfonate (MMS) in mouse bone marrow cells. Indian J Exp Biol 1996; 34 (6): 502-507.

16. Topaktas M, Rencuzogullari E, Basri Ila H. In vivo chromosomal aberrations in bone marrow cells of rats treated with Marshal. Mutat Res 1996; 371: 259-264.

17. Evans EP, Breckon G, Ford CE. Air drying method for meiotic preparations from mammalian testes. Cytogenetics 1964; 3: 289-294.
18. NorizadehTazehkand M, Topaktas M. The in vitro genotoxic and cytotoxic effects of remeron on human peripheral blood lymphocytes. Drug ChemToxicol 2014; 26: 1-6.

19. Paz-y-Mino C, Bustamante G, Sanchez ME, Leone PE. Cytogenetic monitoring in a population occupationally exposed to pesticides in Ecuador. Environ Health Perspect 2002; 110: 1077-1080.

20. Yavuz-Kocaman A, Rencuzogullari E, Ila HB, Topaktas M. The genotoxic effect of potassium metabisulfite using chromosome aberration, sister chromatid exchange, micronucleus tests in human lymphocytes and chromosome aberration test in bone marrow cells of rats. Environ Mol Mutagen 2008; 49: 276-282.

21. Mace JML, Daskal Y, Wray W. Scanning electron micros-copy of chromosome aberrations. Mutat Res 1978; 52: 199-206.

22. Kaya FF, Topaktaş M. Genotoxic effects of potassium bromate on human peripheral lymphocytes in vitro. Mutat Res 2007; 626 (1-2): 48-52.

23. Tong L, Yu KN, Bao L. Low concentration of exogenous carbon monoxide protects mammalian cells against proliferation inducedby radiation-induced bystander effect. Mutat Res 2014; 759: 9-15.

24. Rencuzogullari E, Yildiz AM, Buyukleyla M. The genotoxic and anti-genotoxic effects of Stachyspetrokosmos leaf extract in human lymphocytes using microsomal fractions. Cytotechnology 2012; 64 (1): 83-94.

25. Alves de Lima RO, Azevedo L, Riberio LR, Salvadoi DMF. Study on the mutagenicity and antimutagenicity of a natural food colour (annalto) in mouse bone marrow cells. Food Chem Toxicol 2003; 41: 189-192.

26. Gasiorowski K, Szybaa K, Brokosa B, Kozixlilaczynska B, Jankowiak-Wzixlilodarczyka M, Oszmianski J. Antimutagenic activity of anthocyanins isolated from Aroniamelanocarpa fruits. Cancer Lett 1997; 119 (1): 37-46.

27. Agnera AR, Barbisana LF, Scolasticia C, Salvadoria DMF. Absence of carcinogenic and anticarcinogenic effects of annatto in the rat liver mediumterm assay. Food Chem Toxicol 2004; 42 (10): 1687-1693.

28. Santos CDG, Mendonça LM, Antonucci GA, Cardozo Dos Santos A, Antunes LMG, Bianchi MLP. Protective effect of bixin on cisplatin-induced genotoxicity in PC12 cells. Food Chem Toxicol 2012; 50 (2): 335-340.

29. Edenharder R, Tang X. Inhibition of the mutagenicity of 2-nitrofluorene, 3-nitrofluoranthene and 1-nitropyrene by flavonoids, coumarins, quinones and other phenolic compounds. Food Chem Toxicol 1997; 35: 357-372.

30. Hannah C, Priya EJS, Mammen A. Duration dependent mutagenic study of Cola drinks on Allium cepa L. Biosci Biotechnol Res Asia 2010; 7 (2): 807-812.

31. Jensen NJ, Willumsen D, Knudsen I. Mutagenic activity at different stages of an industrial ammonia caramel process detected in Salmonella typhimurium TA 100 following pre-incubation. Food Cosmet Toxicol 1983; 21: 527-530.

32. Rayes AAH. Effect of Some Drinks on the Benificial Probiotic Bacteria and the Structure of Testis of Male Albino Mice. J Appl Sci Res 2008; 4 (7): 803-813.

33. Urry LA, Michael L, Steven A, Peter V, Robert B, Jane B. Campbell Biology in Focus, 2014; Benjamin Cummings. UK.

34. Hidaka M. Physiological activity of 4-methylimidazole. III. Absorbance and excretion rate of 4-methylimidazole in the organ. Okayama Igakkai Zasshi 1976; 88: $665-671$.

35. Hargreaves MB, Jones BC, Smith DA. Inhibition of pnitrophenol hydroxylase in rat liver microsomes by small aromatic and heterocyclic molecules. Drug Metab Dispos 1994; 22: 806-810.

36. Karangwa E, Mitchell GE, Tucker RE. Pharmacokinetics of 4-methylimidazole in sheep. J Anim Sci 1990; 68: 3277-3284.

Received September 8, 2015. Accepted September 23, 2015. 